Working with families of at-risk and special needs students: A systems change model

Lambie, Rosemary

Focus on Exceptional Children; Feb 2000; 32, 6; Research Library

pg. 1

VOLUME 32

NUMBER 6

FEBRUARY 2000

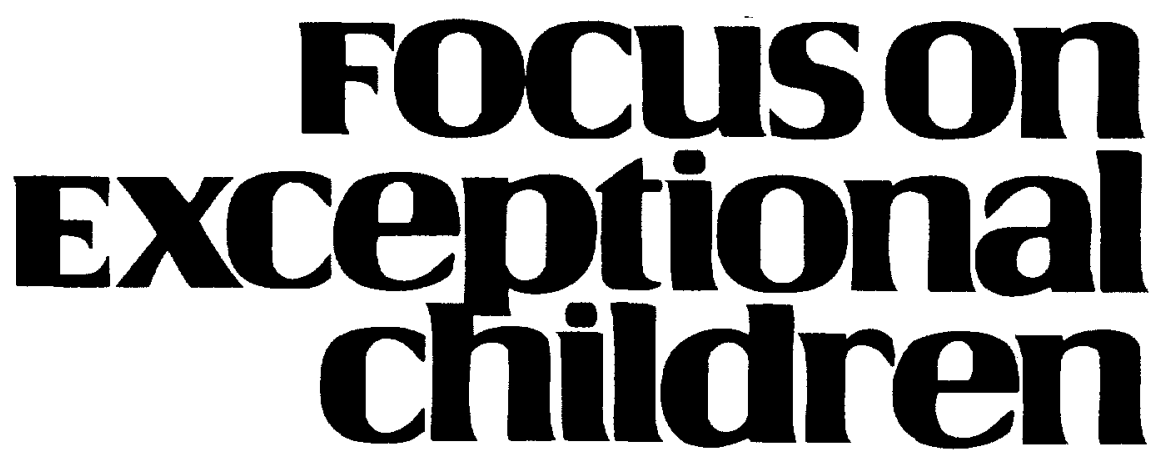

\title{
Working with Families of At-Risk and Special Needs Students: A Systems Change Model
}

\author{
Rosemary Lambie
}

\begin{abstract}
This article provides some basic foundation of family systems concepts for school professionals who work with students who are at-risk or have special needs. It gives information for both the general educator and special educator. The ideas will be helpful when you collaborate with parents and other professionals. It covers communication skills and psychological issues that can result in barriers to implementation of family systems concepts in the schools.

The discussion then turns to problem solving and a five-step process leading to conflict resolution. A section on interaction between families and schools follows, highlighting five aspects of working with families. Potential limitations to using family systems concepts in schools that stem from lack of training, school norms, and school procedures are then discussed, followed by a discussion of the reality constraints of time, money, and availability of trained personnel. The final section focuses on attitudes, resistance, and change. This section identifies the stages of response to change, addresses concerns about change, and ends with a major focus on Satir's model for change.
\end{abstract}

\section{COMMUNICATION SKILLS}

Parents' communication skills vary widely. Some parents are quite articulate, while others struggle to make even the simplest point. Some parents will not even try to communicate because they are afraid that they will sound foolish or inadequate. Beyond parents' communications skills lie the communication skills of everyone else involved in school-family interactions, including professionals, others in the student's life, and the student. This section begins with a discussion of parental communication, focusing on reasons for communication problems and the need for parent training. The focus then shifts to the many different levels on which people communicate, which Satir (1983a) referred to as the ingredients of an interaction. An understanding of these ingredients is important for preventing miscommunication.

Rosemary Lambie is a Professor of Education in the School of Education at Virginia Commonwealth University, Richmond, Virginia. This article is adapted from a new book Family Systems Within Educational Contexts published by Love Publishing Company.

(C) Love Publishing Company, 2000 


\section{Parental Communication}

It is important to help parents learn the communication skills needed to articulate their views and not feel overwhelmed by their team experiences. It is infinitely possible for parents to help one another by sharing their experiences; however, Morsink et al. (1991) questioned using parents as teachers. Whether parents or professionals provide the training, it is important to augment parenting skills if children are to succeed in school. In Raising Our Future (1995), the Harvard Family Research Project presented a national resource guide for families. Many of the resources listed include training for parents.

\section{Inadequate Processing of Information}

Communication problems can arise because parents are unfamiliar with the procedures employed on teams or because they have not mastered effective communication skills. These problems are relatively easily remedied. There are also parents who may be inarticulate due to a personal disability. Some parents with retardation may have trouble processing information given to them by the schools. Losen and Losen (1985) suggested that someone might accompany

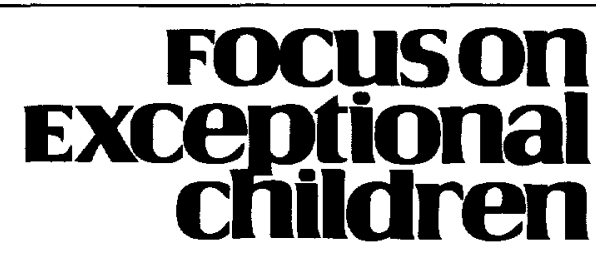

ISSN $0015-511 \mathrm{X}$ FOCUS ON EXCEPTIONAL CHILDREN (USPS 203-360) is published monthly except June, July, and August as a service to teachers, special educators, curriculum specialists, administrators, and those concerned with the special education of exceptional children. This publication is annotated and indexed by the ERIC Clearinghouse on Handicapped and Gifted children for publication in the monthly Current Index to Joumals in Education (CIJE) and the quarterly index, Exceptional Children Education Resources (ECER). The full text of Focus on Exceptional Children is also available in the electronic versions of the Education Index. It is also available in microfilm from Xerox University Microfilms, Ann Arbor, MI. Subscription rates: Individual, $\$ 30$ per year; institutions, $\$ 40$ per year. Copyright (C) 2000, Love Publishing Company. All rights reserved. Reproduction in whole or part without written permission is prohibited. Printed in the United States of America. Periodicals postage is paid at Denver, Colorado. POSTMASTER: Send address changes to:

$$
\begin{gathered}
\text { Love Publishing Company } \\
\text { Executive and Editorial Office } \\
\text { P.O. Box } 22353 \\
\text { Denver, Colorado } 80222 \\
\text { Telephone (303) } 221-7333
\end{gathered}
$$

$\begin{array}{cc}\begin{array}{c}\text { Karen Harris } \\ \text { University of Maryland }\end{array} & \begin{array}{c}\text { Thomas Skrtic } \\ \text { University of Kansas }\end{array} \\ \text { James Shriner } & \text { Stanley F. Love } \\ \text { University of Illinois } & \text { Publisher }\end{array}$

them to IEP conferences to interpret what is happening. If a case worker is assigned to the family, that person is a logical possibility because he or she has already formed a trusting relationship with the parents. Some parents who do not understand the IEP process or what is being said may become disruptive and be unwilling to admit their lack of understanding. When these parents refuse to sign off on a placement recommendation, the school system can request a due process hearing. Seldom would one want to use that alternative, but it is a possibility. Miller (1996) recommended that parents bring a trusted person with them to school functions to increase the likelihood of their continued involvement with the school.

\section{Parent Training}

A number of professionals have written about parental/ family involvement with special-needs children and youth (S. K. Green \& Shinn, 1995; Jenson, Sheridan, Olympia, \& Andrews, 1994; Kay et al., 1994; Sussell et al., 1996; Turnbull \& Turnbull, 1996). This literature has focused on parental involvement, parents as teachers, parents as partners, homework, teamwork, and attitudes toward the delivery of services. However, finding research on the training provided to parents is difficult. Most articles and books are devoted to involving parents in activities that don't involve training or on descriptions of the different kinds of parent effectiveness training aimed at the general population, such as Systematic Training for Effective Parenting (STEP).

McLoughlin (1981) described a parent/teacher education model for the joint training of teachers and parents of children with disabilities. The model involved competency-based, skills-oriented training and focused on "training together to work together," with the outcome being enhanced cooperation and interaction. The project demonstrated that joint training can be effective in gaining the involvement and support of these parents.

Leithwood (1997) found that parental involvement in children's education accounted for $50 \%$ of the variance in the school achievement of children. Based on this finding it is incumbent upon educators to provide training to parents. Many others agree. Yet, still, for some school professionals, the idea of training parents to be involved in their child's education remains a low priority. Turnbull and Turnbull (1996) reported that there are 71 Parent Training and Information Centers funded by the federal Department of Education. Each state has at least one PTI, as do Palau and Puerto Rico. Turnbull and Turnbull listed the centers in an appendix in their text.

\section{Ingredients of an Interaction}

Parents, students, and professionals will better meet students' needs if they communicate more effectively. It can be 
confusing to wade through the levels of human interactions to determine the meaning intended as well as the meaning ascribed to interactions. By learning about Satir's ingredients of an interaction professionals will be better able to sort out as well as respond to the various ingredients, thereby improving their communication.

Prior to going further in describing the ingredients it will help to have some information on two central concepts from Satir's work.

\section{The Stances}

This section describes each of Satir's (1988) five stances from the perspective of how these stances look to others. It also looks at the internal states of people assuming these stances and the underlying reasons for taking on the dysfunctional stances. Further, it describes how the dysfunctional stances appear when they have been renovated or transformed, with strengths growing out of former weaknesses. Finally, the aspects of communication-self, other, and context, including purpose, time, and place of communication-that are violated or discounted with each type of dysfunctional communication are delineated (Satir, 1988).

\section{Placating}

One who assumes a placating stance is trying to conceal personal vulnerability by striving to please others. The placater will go along with something out of the need for emotional survival rather than because of personal commitment and interest. A placater rejects or discounts self when doing what others expect; his or her actions derive from not wanting to be rejected by others. The placater seems like a nice person who avoids conflict and turning others down. Although protective of others, this person is really quite dependent and fragile.

Through a transformative process and letting go of past dysfunction, the placater makes choices that affirm self as opposed to seeing self as worthless unless approved of by others. The placater who has gained a sense of personal worth has the capacity for being tender and compassionate. Transformed, the placater genuinely cares for others.

\section{Blaming}

The individual who takes a blaming stance is attempting to mask personal vulnerability by trying to control others as well as by indiscriminately disagreeing with them. This stance allows the blamer to feel a greater sense of personal importance in spite of the experience of loneliness and personal sense of failure. This person will complain, bullying others and finding fault with them. One who assumes a blaming stance discounts the other person or people.

Blaming can be transformed into being assertive and taking a stand for oneself. When standing up for oneself, the blamer learns to assert self realistically, as opposed to having a knee-jerk reaction to others.

\section{Superreasonable (the computer)}

A person assuming the stance of superreasonable seeks to disguise vulnerability with a detached control that focuses on intellectual experience. This focus allows the person to skirt emotions and thereby anesthetize feelings. This person is cool, aloof, reasonable, and intellectual; his or her clear persuasiveness should not be confused with congruent communication. This type of communication discounts both self and other.

A person who is superreasonable can learn to use his or her intelligence creatively, as opposed to using intelligence to protect self. The professional will sense the connection with emotions in the transformed superreasonable and be aware of this person's wisdom.

\section{Irrelevant (the distractor)}

The individual who takes on the irrelevant stance is pretending that the stressor is nonexistent. He or she diverts the focus from the present, feeling-laden situation to something else. To others, that diversion may appear quite off-the-wall. Non sequiturs and scatterbrained comments frequently are observed. This type of communication discounts self, others, and context.

Transformed, the formerly irrelevant person has the ability to be spontaneous and have fun. This person becomes a creative individual capable of congruent interactions, having no need to discount self, others, or eontext.

\section{Congruent}

According to Satir (1988), a congruent person provides leveling responses in which the outward expression, actions, and tone of voice fit the spoken word. Not feeling a need to hide or conceal personal feelings, this person has high self-esteem and loves and values self. Furthermore, others and context do not need to be discounted. This person is balanced; he or she is centered in the truth of his or her own feelings and beliefs. Not afraid to challenge the status quo, a congruent individual takes risks to grow and change. He or she also assumes responsibility for personal thoughts, feelings, and actions.

Also useful for background before describing the ingredients of an interaction is a listing of Satir's Five Freedoms.

\section{SATIR'S FIVE FREEDOMS}

Satir saw the following five freedoms as the cornerstone to effective human communication (Schwab, 1990):

1. To see and hear what is here, instead of what should be, was, or will be. 
2. To say what one feels and thinks instead of what one should.

3. To feel what one feels, instead of what one ought.

4. To ask for what one wants, instead of always waiting for permission.

5. To take risks in one's own behalf, instead of choosing to be only "secure" and not rocking the boat. (Satir \& Baldwin, 1983, pp. 168-169)

So, what are the ingredients of an interaction? They are everything that goes into making communication (Baldwin, 1993; Schwab, 1990). Satir (1983a) compared communication to a recipe with many different ingredients. A person's interactions with others can be seen as enjoyable and as complex as making that new recipe for the evening meal. It is easy to misread communication if you are not aware of all of the ingredients. Just as leaving out the baking powder in a recipe can result in flattened cookies, failure to understand, recognize, or respond to an ingredient of an interaction can result in flattened communication.

\section{Ingredients}

Satir described seven ingredients in communication (Azpeitia \& Zahnd, 1991; Satir, 1983a; Schwab, 1990). Figure 1 shows these ingredients for a two-person interaction involving spoken communication. Point 1 is the initiating point, and point 8 is the responding point of the communication.

Person A, named Adam, initiates a message to Person B, Betty. The other six ingredients of the interaction (points 2-7) are part of Betty's internal process before she responds at point 8 .

Point 2 represents Betty's internal process of figuring out what she sees and hears. She uses her eyes, ears, skin, and so forth, to determine what she sees and hears. If she cannot see because she is on the phone or she is blind, she will not have all those avenues of determination open to her. Assuming that she can see, Betty will take in Adam's facial expression, body position, muscle tone, skin color, scent, smell, breathing, voice tone and pace, as well as movement. These factors are called paralinguistics; they provide well over half of the meaning of the message. Adam's words are only part of the message. How Adam delivers the words will convey much meaning. Betty will select what she hears and sees from all the possibilities.

Next, point 3 is Betty's connecting with past experiences and learning, which will determine the meaning she will make of what she sees and hears. Betty might well ask herself, while forming the meaning of the message, how aware of the past and present she is as they relate to self, other, and context. She also could ask herself whether she was aware of any past experiences that could contaminate the meaning she makes of the message from Adam.

Point 4 in the diagram represents the feelings triggered within Betty about the meaning she made of the message conveyed by Adam. Betty might ask herself the question, "What feelings do I have about the meaning I have made of the communication?" Note that Satir (1983a), like many people in the field of mental health, believed that feeling stems from the meaning or belief a person holds about an event, situation, or communication (M. P. Nichols \& Schwartz, 1995).

In turn, the feelings activate point 5 , which is related to feelings about the feelings. Satir (1983a) asked the question, "What are my feelings about the feelings about the meaning?" At first this may seem roundabout. Consider, however, that Betty may feel angry about the meaning and feel guilty about feeling angry. The feelings associated with the feelings about the meaning need to be sorted out. It is one situation if Betty feels that her feeling of anger is fine and another if she feels guilty about feeling angry. Both communication stances and family rules come into play. The




feelings about the feelings activate survival rules. Thus, coping stances will come into play if the person discounts self, other, context, or two or three of these. The person is easily caught in an old web of feelings.

Point 6 stems from point 5 and relates to defenses Betty uses. These include such defense mechanisms as denying, projecting, and distorting. If she is using defenses, Betty could look to see whether she would cope by blaming, placating, being superreasonable, or being irrelevant. If, however, Betty owns and accepts her feelings, she does not have to defend herself and can decide how she chooses to respond.

Point 7 represents rules for commenting. Must Betty see what she "should," say what is expected, feel what she "ought," and wait for permission, choosing to be secure and not rock the boat? Or can Betty exercise the five freedoms? In owning and accepting her feelings, she creates internal safety and does not have to defend herself. She is free to take risks and has choices for what and how she would like to respond to Adam.

At point 8 Betty responds with a message. Ideally, Betty will have made a meaning that matches the meaning intended by Adam. By accepting and owning her feelings, acknowledging and valuing Adam's feelings, as well as considering the context, Betty can take responsibility for her response and express herself in a congruent mode.

The communication, however, is not over yet. Now Adam must go through the same process that Betty just did. Figure 2 represents points 9 through 15, as Adam goes through the same steps in the process that Betty went through in points 2 through 8 .

As indicated by this discussion, communication is more complex than is immediately obvious. There are many places where problems or snags might be found. Understanding one's own process is necessary before understanding that of others.

\section{Effect of Communication Stances}

The complex communication process becomes even more complex when one or both people are not communicating congruently. Several variations are possible. Both partners could communicate congruently, or both could communicate incongruently. Person A might be congruent and person $\mathrm{B}$, incongruent. Person $\mathrm{B}$ might be congruent and person $\mathrm{A}$, incongruent. Imagine the possibilities within a family!

Each person in an interaction must consider the internal process of the other. There are many possible ways of misinterpreting others, and miscommunication is more than occasional. That is understandable in light of the variations in stances that may exist. Being aware of the four possibilities is essential when communicating with others. To be unaware of the possibility that one's partner might be incongruent or congruent, and that you might also be either one, would lead to even greater problems when communicating. Recognizing how easy it is to miscommunicate underscores the need to clarify any communication that seems unclear or that you are unable to read accurately.

When trying to clarify what another person means by a message, you can look to the ingredients of the interaction for potential assistance. You will need to think about how the person made meaning from your original message, how he or she felt about that meaning and about the feeling about the meaning. Then you will need to try to decipher the defenses employed or the stances assumed as well as determine any freedoms violated by the person`s rules for commenting.




Before trying to understand another person's process, it helps to have examined your own.

\section{Examining Personal Process}

Understanding your own process is the first step in being able to use your knowledge about the ingredients of an interaction. Beginning your investigation with a current interaction is laudable; however, it might be easier to start by recollecting a recent, simple, meaningful interaction. It is valuable to recall, as well as memory allows, each of the components in that interaction. You should think back to the first comment made during the interaction by the other person and then determine the meaning you attached to it as well as the feelings you experienced about that meaning. You should then determine your feelings about these feelings, even if you were not aware of them at the time. Look to what defenses you used. That type of analysis can help you better understand your response. There is no way to know the internal process of another without engaging in what is called mind rape. You might, however, try to infer each of the components that form the internal process of the other person. This is merely inference and good practice.

After analyzing a past interaction, you can benefit from analyzing several other past interactions to see if any patterns emerge. Are there certain types of meaning made from a particular type of message? Are there feelings attached to meanings that provide a better picture of yourself? Can you determine defenses or rules operating under different feelings about feelings? By answering these questions, you can analyze your personal communication style. This type of analysis will serve professionals well when they attempt to transform family rules that would perform better as guidelines.

The next task is to analyze the ingredients while an interaction is occurring. For one day, while interactions are occurring, analyze those interactions that present a low level of threat. Once you have successfully finished that task, the next step is to analyze the ingredients of a current interaction that is potentially emotionally laden. It is important to not make too large a leap from an interaction that is low threat to one that is high threat, or your internal process may be too hard to follow. The amazing thing about communication is that everyone unconsciously and continually goes through this internal process throughout each day, giving little thought to the internal process.

\section{Application Process}

Although it is not possible to apply the ingredients of an interaction, an awareness of these ingredients is helpful for overcoming barriers to working with families as well as for gaining access to support groups, networking, and referring to counseling.
Miscommunication often occurs when a professional conveys to parents the need for additional assistance. Parents frequently mistake that comment as a judgment about their adequacy as a family or as individuals. Clearly, they are uncomfortable when others judge them to be inadequate. Knowing that parents might interpret any recommendation as a judgment of inadequacy can help professionals prepare their communications so that they are more likely to be understood as intended.

Any referral recommendation should begin with statements about realities within the family and should be followed by comments about the positive effects of the intervention on other families or individuals. It is important to use a positive frame when presenting any recommendations. For example, the professional could say, "All of us could use external assistance at times of stress and transition. This is not a sign of inadequacy or even dysfunction, but a normal reaction to stress." Then the specific issues can be linked to the need for additional assistance. When the professional is aligned with the family, they are less likely to see the professional as having judged them as inadequate.

\section{PSYCHOLOGICAL ISSUES}

School professionals, unlike professionals in mental health centers and child guidance clinics, often do not have the luxury of working with parents who recognize that they may be contributing to their child's problems. What is often found in schools is that parents are unaware that they have somehow played into their child's school difficulties. Losen and Losen (1994) discussed passive parents who defer to school professionals and seem unaware of their own collusion through being uninvolved.

Losen and Losen (1985) also stated that no matter how experienced the team members are in family dynamics, "parents may not be willing to accept even the hint of a suggestion during a team meeting that they are in any way responsible for their child's problems" (p. 113). Such parents should not be confronted in team meetings. Instead, it is important to ensure parental cooperation before including parents in team meetings during which decisions about their child will be made.

Although infrequent, problems involving parents who are defensive or belligerent do occur. These problems frequently stem from alcoholism, divorce, and psychiatric difficulties. The next sections briefly discuss aspects of these types of problems and suggests means for dealing with them.

\section{Demanding Parents}

Most legalistic and demanding parents have experienced prior incidents that led them to mistrust authority. They may 
easily misread the school's efforts to provide procedural due process as trying to "pull a fast one on them." It may be helpful to allow a trusted friend of the family or a professional to act as a go-between with the school. At all times, it is important to keep the focus on the best interest of the student. Eventually, parents will hear the call to what is in their child's best interest. An outside evaluation, conducted by an impartial evaluator, may help some parents feel better. If parents consider such an option, any evaluators recommended by the school should be independent and not vanguards of the system. The following case example illustrates why independent evaluations can be useful.

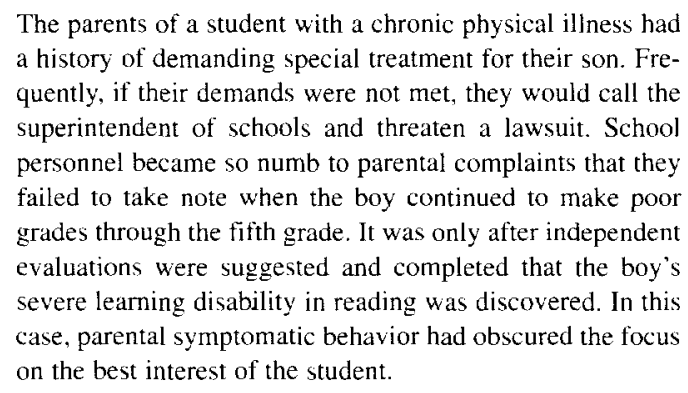

There are some rules of thumb (Losen \& Losen, 1994) that will help school professionals when dealing with demanding and legalistic parents. As suggested earlier, parents should not be confronted during team meetings. If a conflict erupts unexpectedly during a team meeting, it is best to table any decisions until the conflict has been resolved. Any hostility or mistrust should be validated, and, obviously, strong feelings should not be denied or ignored. The school professionals should discuss with the parents the origin of their concerns as well as their underlying fears.

The team also should let the parents know when they are on target in making a fully intelligible and defensible point of view. A good comment is, "If I were in your place I probably would be feeling the same way," or "Although I do not see it that way, I do understand your belief and thus the feelings you have about this situation."

When parents become flexible, school professionals must be sure not to remain rigid in response. It is better to have a good beginning toward what is best for the student than a due process hearing that may make things worse.

\section{Psychiatric Difficulties}

Parents with emotional problems may be unsupportive and unresponsive, needy and seeking continual input and reassurance, or emotionally unstable and disruptive as well as irresponsible. Working with such parents may leave any school professional feeling in a one down position.

Regardless of the type of disruption, it is important that the professional reassure the parents of his or her commitment to their child. It may also be necessary to clarify and explain rationale and procedures. Further, the team needs to work with irrational parents prior to conducting any meetings. Parents can meet individually with the professional with whom they share the best rapport. Some parents would benefit from referral for family systems therapy; the social worker could make this recommendation while meeting with them. It is more likely that the parent will provide more meaningful and honest input with one open and supportive professional than at a team meeting.

An alcoholic parent should not be invited to a private conference. Alcoholics' behavior may be unpredictable, and they may be difficult people. If they insist on attending and are obviously under the influence of alcohol or other drugs, the meeting should be terminated immediately. Professionals must be careful, however, that such parents do not feel put down by this action and should help them in any way possible to reclaim their self-esteem. Following the meeting, it might be helpful to share information with the nonalcoholic parent about local Alcoholics Anonymous or Al-Anon chapters).

Professionals (Losen \& Losen, 1985, 1994; Morsink et al., 1991; Turnbull \& Turnbull, 1996) have suggested many effective strategies for working with unstable parents. Some recommendations are that the professional attempt to clarify the parents' understanding of their child's problem, that the professional provides more reassurance than is usually needed, that a strong relationship be established between one team member and the parents during individual conferences as a precursor to team meetings, and that school comments be directed to the most stable or rational parent. When working with unstable parents, refraining from exchanging angry words is a must. However, professionals should not refrain from calling upon external resources such as police, friends, or a minister.

\section{Angry Parents}

Dealing with angry or aggressive parents has been addressed by various professionals (Armstrong, 1995; Losen \& Losen, 1994; Morsink et al., 1991; Turnbull \& Turnbull, 1996). Margolis and Brannigan (1986) published a useful article titled "Relating to Angry Parents." Dealing with angry and aggressive parents is part of a professional's job in the schools, yet maintaining composure under direct attack and confrontation is not an easily developed skill. Even more difficult is empathizing with parental fears and frustrations. These are important skills for all school professionals.

Even sane, rational parents may become angry and let their anger show. School professionals need to recognize that parents may have valid complaints, or that a mistake may have been made. Working with the parents to help them vent their feelings and share their understanding of the problem is critical. However, it is definitely not advisable to give 
in to aggressive parents when the option is not in the child's best interest.

The following are some rules of thumb for dealing with angry parents. Professionals should always make eye contact and be courteous. They should not try to interject their own opinions. Instead, they should listen to the parents. If the professional does not understand the underlying concern because of the level of anger being expressed, a clarification should be requested. The professional should listen actively, reflecting the parents' beliefs and feelings. Summarization of the parents' points also may be helpful. If the parents disown any mention of their anger, the professional should steer clear of further comments and relate to the parents' beliefs. The important point in dealing with angry parents is to not try to solve the situation but instead to build trust by demonstrating caring and concern.

The professional should also try to distinguish true issues from pseudo concerns, asking questions that assist in this process. The questions should be open-ended, such as, "How is it that this came about?" Questions that begin with "why" should be avoided because they may lead to defensiveness in the parents. Once everything is out in the open, the professional should summarize the points of agreement as well as disagreement. The professional should then determine if the parents have anything to add that would further clarify everyone's understanding.

All of these steps provide for exploration and understanding of the problem from the parent's point of view. As noted earlier, the emphasis is on connecting and building trust. The next step is problem solving. D. Johnson (1997) presented a number of exercises designed to help professionals, students, and parents in developing and refining their human interaction skills. Chapters in Johnson's textbook relate to psychological issues and focus on listening, resolving interpersonal conflicts, and managing feelings related to anger and stress. Though oriented toward the preparation of professionals, the exercises can be used in training parents as well as students in healthy human interaction skills. The problem-solving process will now be discussed briefly.

\section{PROBLEM SOLVING}

Problem solving is a multistep process that leads to conflict resolution. The five steps presented in this section are critical to group problem solving. The steps are time-honored; most problem-solving models are only slightly different variations of the one described here. Teams are involved in continual problem solving concerning team process issues as well as content concerns (Losen \& Losen, 1994).

\section{Step 1: Define the Problem}

No one can effectively solve a problem that is not well defined. Although most team members expect that defining the problem will be an easy step in the process of problem solving, in reality, it is a challenging step.

It is important that all team members focus on the underlying cause of the problem and not on the symptoms. People often become wrapped up in symptoms and fail to see the forest for the trees. If, for example, a student is having trouble concentrating and staying in his seat in school, many professionals will focus on the surface manifestations of the problem-that is, the student's in-school behavioral excesses. By more thoroughly examining the problem, however, the team might find that no parent is available to supervise the student in the mornings before school. Lacking supervision, the student might be getting hyped up by eating junk food and watching overstimulating videos before going to school. Thus, the problem would be accurately defined as one that originates at home rather than in the classroom.

\section{Step 2: Collect Facts and Opinions}

Once the problem is understood, the team members gather the facts and opinions needed for further understanding the situation. It may not be possible to obtain all the facts, but it is important to move forward and not allow the situation to become a crisis. It is critical to find out what the situation is, what happened, who is involved, and what policies and procedures are involved. All of those factors will help team members design realistic solutions.

\section{Step 3: Generate Solutions}

This step involves brainstorming for possible solutions. No idea should be criticized at this point. When team members criticize or evaluate ideas at this stage, they effectively shut off the production of creative solutions. This step should be freewheeling and fast-moving, with everyone on the team providing potential solutions.

\section{Step 4: Select the Solution}

There are two aspects to the fourth step. First, the team must clearly specify the goals, or end results, they expect from the solution. Then, they must evaluate each of the solutions generated in the previous step in light of the agreed-upon goals. The few solutions that come out on top should be put to the tests of potential feasibility and maximization of resources. Based on those tests, the best solution is selected.

\section{Step 5: Implement the Solution}

Timetables for the solution should be established by team members. Further, the team should specify the evaluation techniques to be used and make plans for follow-through. 


\section{INTERACTION BETWEEN FAMILIES AND SCHOOLS}

This section focuses on four aspects of working with families. First, the need, desire, and availability of family members to be involved in the education of the at-risk or special-needs learner are considered. Second, a family systems perspective on team issues is addressed. Third, reasons for nonparticipation, and fourth, ways to overcome unwanted nonparticipation, and means of involving families who want to participate are covered.

\section{Need, Desire, and Availability of Family Members}

It is important that team members consider the desires and availability of family members for involvement on the team (Armstrong, 1995; Carney \& Gamel-McCormick, 1996; Foster et al., 1981; Losen \& Losen, 1994; PowerdeFur \& Orelove, 1997; Turnbull \& Turnbull, 1996; Winton \& Turnbull, 1981). Some parents might want to be more involved than their schedules and responsibilities allow. Other parents might not be interested in involvement, regardless of other responsibilities, and their choice should be respected by educational professionals. Bjorck-Akesson and Granlund (1995) reconfirmed the 1981 findings of C. Lusthaus, E. Lusthaus, and H. Gibbs that parents wanted to be involved in schools by giving and receiving information. Parents also were found to be interested in being involved with decisions about the "kinds of information kept on their children; medical services for their children; and transfer of their children to other schools" (p. 257).

Professionals currently maintain that school personnel should encourage family involvement while also recognizing that there are a variety of reasons for limited participation or nonparticipation. Those reasons are elaborated upon later in this article. Z. P. Solomon (1991) reported on California's policy relating to parental involvement in schools. California recommended six ways to design programs to involve parents:

\footnotetext{
1. Help parents develop parenting skills and foster conditions at home that support learning:

2. provide parents with the knowledge of techniques de signed to assist children in learning at home;

3. provide access to and coordinate community support services for children and families;

4. promote clear two-way communication between the school and the family as to the school programs and children's progress;

5. involve parents, after appropriate training, in instructional and support roles at school; and

6. support parents as decision-makers and develop their leadership in governance, advisory, and advocacy roles. (p. 361 )
}

These guidelines are as pertinent to at-risk and special-needs families as they are to all other families. More specific ways to involve parents in schools were described by BjorckAkesson and Granlund (1995), Chapman (1991), D'Angelo and Adler (1991), Z. P. Solomon (1991), and Sussell et al. (1996).

After researching family involvement, Winton and Turnbull (1981) suggested that schools match parental involvement to the individual needs of families. They further indicated that parental uninvolvement will sometimes be a tremendous contribution to the school program. Although professionals may assume that they are acting in the best interests of the student by encouraging parental involvement in their program, in some cases this is not true.

Turnbull and Turnbull (1996) indicated that parents should be provided with options for involvement. One option would be uninvolvement with the school program as a matter of choice. Another option would be involvement through being informed about, but not participating in developing, goals and objectives. A third option would be full and equal decision-making opportunities for parents who choose to participate at that level.

\section{Family Systems Perspective}

The focus of an edited text by W. M. Walsh and G. R. Williams (1997) is on the use of family systems theory and therapy to resolve school problems. A book about change, it focuses on a paradigm shift that leads people toward systems thinking. The editors wrote, "When we conceptualize students' problems as a part of an interactional dynamic within a system and work to change those interactions and ultimately the system, students improve" (p. xiii).

Peeks (1997) suggested that the revolution in counseling related to the theory and practice of family therapy should provide the basis for a revolution in public education. She proposed that "one of the important elements of educational reform be focused on the relationship among parents, students and school professionals. Students should be helped by their parents and school working as a cooperative problem solving team" (pp. 5-6). Students who are problem-free were described as able to achieve to their potential, thus improving the collective achievement in the school. It also was suggested that students would benefit by observing their parents' involvement in their education. According to Peeks, as problems of students are solved by parental input, higher quality education would follow.

Malatchi (1997) framed the educational paradigmatic shift in relationship to the education of children with special needs. She saw the shift as a movement from a system-centered approach to one that is family/person-centered. The edited text (Power-deFur \& Orelove, 1997) in which her chapter appears elaborates on how to put such an approach into action in the schools. Briggs (1997), focusing on family systems as a base for early intervention, stated, "Professionals 
can learn to move their focus away from treating the child with special needs as the identified patient. With a broader focus, the family system is no longer a problem but part of the solution" (p. 107).

As early as 1983, Pfeiffer and Tittler described how eligibility teams could benefit by adopting a family systems orientation. Their approach recognized that families and schools are intimately interrelated and linked through the student. By shifting to a family focus, the referred student is no longer viewed in isolation but within the context of his or her family. By observing the family, team members can better understand and predict the student's behavior in school as well as social functioning in the family. Also, if other family members can be helped to redirect some stress from the student, the student's dysfunction should lessen, with an increase in the possibility for remediation in school.

\section{Reasons for Nonparticipation}

Carney and Gamel-McCormick (1996), as well as Morsink et al. (1991), indicated that while it is important for professionals to respect the right of parents to choose not to participate in their child's educational program, it is also important to determine whether the nonparticipation is based upon an informed choice. Lack of parental participation might be related to specific child and family characteristics rather than choice. D. L. McMillan and A. P. Turnbull (1983) had previously reached the same conclusion, as had Suelzle and Keenan (1981), whose findings indicated that families with lower incomes, older children, and children with more severe disabilities were less likely to be involved in their child's education.

Weber and Stoneman (1986) investigated the differences in family characteristics, maternal knowledge about the IEP process, and the mother's knowledge about the IEP itself for parents who did and did not attend IEP meetings. They found that poor families with limited parental education who were nonwhite and who were headed by single parents were overrepresented in the group of parents who did not attend the meetings. Mothers who viewed teachers and other professionals as responsible for their child's education were often nonparticipants. The authors considered it important to reach out to families, to provide programs responsive to their particular needs that are sensitive to the demands faced by the parents, to empower the parents, and to provide them with a sense of control. They indicated that parents are able to make informed choices about participation in their child's education when they fully understand both the rights and the opportunities that are available from the schools. They concluded that many parents lack basic information that is needed to make informed choices.

Parental anxiety contributes to lack of participation (Losen \& Losen, 1994). Parents may be anxious for a variety of reasons. First, they may be concerned about what is happening to the child and feel that they don't have the answers (Miller, 1996). Especially early in the process, parents tend to depend upon team members to identify their child's difficulties and to provide remedial services (Armstrong, 1995). Thus, they may feel somewhat at the mercy of the expertise of the professionals, especially if they are not knowledgeable about their child's problem. Second, parents may be worried that they will appear stupid, confused, or indecisive. Thus, they may restrict their input and be passive during the team meetings they do attend.

Third, parents may feel that they have failed their child. Such a sense of guilt is common among parents of children with special needs (Losen \& Losen, 1994). Parents may be concerned that their parenting skills are being judged or evaluated negatively by professionals and that they have made mistakes that resulted in their child's disability. These thoughts would naturally lead to passivity on the part of parents. They might think that the professionals involved would have better solutions.

Fourth, parents may mistrust the school staff. They may believe that the professionals had misdiagnosed their child or that the professionals might not be competent to deal with the special needs of their child (Losen \& Losen, 1994). Some of these parents resign themselves to professional input; others, feeling a sense of helplessness, resist any efforts to reassure them. Concern and doubt about the competence of professionals also could reflect the parents' own personal doubts about how to deal with the needs of their child. Miller (1996) indicated that it is important that school professionals realize that trust is not automatic and that it grows over time and with positive experience. By requesting information from the family and making them part of the team, professionals can help parents realize that their concerns and issues will be addressed and that they are held in respect.

Fifth, parents may be concerned that involvement in special education will cause their child to be seen negatively by other teachers as well as peers. Parents with this fear have generally found it difficult to accept their child's level of need and, thus, remain doubtful about the differences between their child and other classmates (Losen \& Losen, 1994). They may allow the schools to plan programs for their child yet not be supportive of those programs in the home.

Sixth, parental guilt feelings may involve a fear of criticism (Miller, 1996). Feeling that they have failed their children with special needs and others in the process, parents may fear that friends and relatives will learn about their perceived poor parenting skills unless they comply with the recommendations of the school. This is particularly true of parents of children who are belligerent and act out.

An additional reason for parental passivity and lack of involvement with their child's educational program stems 
from prior negative experiences with schools. For example, a prior teacher, principal, or other professional may have led the parents to conclude that to obtain the best for their child they should remain silent. Parents also may fear that their child will be mistreated, or that a more restrictive environment will be recommended if they contribute their own personal opinions to the process. Even though these negative expectations may be unrealistic, it is important to get them out on the table. For example, a parent may have heard through the grapevine that a particular principal is a strict disciplinarian, or that a social worker might be more negative while interacting alone with parents than during a team meeting. Such concerns need to be aired and dealt with if parental involvement is to be achieved.

\section{Overcoming Nonparticipation}

Losen \& Losen (1994) suggested that information be presented to parents prior to team meetings. Their advice is equally applicable to all of the other team participants. When all participants have received information prior to the meeting, more of the meeting time can be devoted to discussion, which increases the likelihood of participation. Further, Losen and Losen suggested that a preteam meeting between the parents and one professional can alleviate sources of nonparticipation and anxiety. They recommended that a professional with good communication skills meet with the parents to discuss procedures used and their child's test results. All questions the parents might have would be answered, and the professional would maintain an egalitarian attitude.

This preteam meeting allows the professional to explain the test results in lay terms and provides parents with the opportunity to raise issues and questions about the process or results without wasting other team members' time. In addition, parents can be made aware of the purposes for the upcoming full team meeting. They may want to suggest that alternative procedures be employed prior to that meeting, such as observing their child in different settings.

By helping to ensure that the parents understand the procedures used, the preteam meeting should help decrease their passivity, defensiveness, or resistance during the team meeting. The preteam meeting also provides an opportunity to deal with parental doubts, guilt, and sense of inadequacy. It is far easier to deal with these issues in an intimate conference than a full team meeting.

Plus, the meeting prevents the pitfall of parents' first learning about significant results of the assessment during the full team meeting. No humane professional would expect parents to be able to respond to learning that their child has, for example, mental retardation, and also help plan their child's education during the same meeting. Falik
(1995) wrote about how families react to having a child with a learning disability.

To involve parents meaningfully in the team process, it also may be necessary to provide services such as baby-sitters and transportation. Pfeiffer (1980) indicated that such strategies were highly successful in increasing parental involvement.

\section{LIMITATIONS}

This section covers limitations on using family systems concepts and approaches in schools. Many of the limitations stem from lack of training, current norms in the schools, and traditional school procedures.

\section{Training}

Traditional university training in general education and special education does not require a course in communication between home and school. Often school principals are the only school professionals required to take a course in school and community relations, and, typically, parents are just one of many topics covered. Realizing that universities generally require no separate course on working with families, one can see that the family systems approach is infrequently considered in teacher-training institutions.

Further, few counselor-education programs require a course on working with families, and none require a course in family systems. School social workers have always been trained to work with families. In fact, that is their major responsibility in most schools. Not all schools of social work, however, train students in family systems approaches. Few school psychologists have training in family systems, though that does appear to be changing. Experts are beginning to recognize that schools have students for only $9 \%$ of their lives and are increasing their curricular focus to include a holistic view (W. M. Walsh \& Williams, 1997).

Although special educators are obviously required to interact with parents on an ongoing basis, they usually are not required to take a separate course in working with families. Special education is a vast subject area, and family systems concepts may not even be included in elective courses. It is more likely that general educators will have taken a course dealing with families, yet few of those courses focus on family systems.

Thus, there is a very large deficit to overcome before people are able to call upon university professors or schools of social work or psychology to teach content related to family systems concepts. Preservice training is very limited, and the in-service needs of all of the professionals already working in schools compound the problem. At a time when requirements for teacher recertification are being relaxed, it is even less likely that teachers will take courses that will prepare them in family systems concepts. 
University systems are slow to change program requirements. Although higher education has been in the process of restructuring, it is unlikely that, without pressure, institutions of higher education will spontaneously provide coursework on family systems. Thus, it behooves those who recognize the value of family systems to assume responsibility for generating interest in such a course. Typically, they will be greeted with a response such as, "We already have an elective course on working with parents" or "We can incorporate that into another existing course." Neither response is appropriate. Family systems is a complex field that requires in-depth study, understanding, and training. W. M. Walsh and G. R. Williams (1997) have chapters on training school counselors in family systems.

Other potential ways to promote preservice family systems training include legislative mandate and school system recommendation. Many states require, by legislative mandate, a separate course in special education. Other states require that special education be covered within the education program, thus allowing colleges and universities to cover the field of special education for general educators within a portion of another existing course. Similar mandates could be recommended for family systems training. Further, informed superintendents might advise schools of education to provide preservice coursework in family systems. Most institutions of higher education respond to input from superintendents.

In-service training is another matter. Although they have changed dramatically in recent years, staff development activities seldom focus upon family systems training for school professionals. The Commonwealth of Virginia did develop a training module on family systems. The school professionals deeply appreciated the content from both a personal and a professional perspective. A trainer-of-trainers model and the use of a team to provide training are highly recommended. It is helpful if one member of the team is knowledgeable about the content and can field questions. The school social worker would be an excellent professional for that perspective.

So far, this section has dealt with limitations in the training of professionals. Another training limitation is the lack of programs that respond to the training needs of parents of at-risk and special-needs students. Few schools provide more than written literature concerning the child study or eligibility process. Parents need more than that. At the very least, parents should be coached in effective communication skills. After all, more effective communicators are also more effective team members.

\section{Norms}

A well-established norm for school professionals is to not become too involved with family matters. With the exception of Project Head Start, schools generally have considered family matters to be the responsibility of agencies external to the schools. Referral to mental health centers is not a common approach taken by school professionals. Due to concern about the cost of related services to the school system, school professionals are even less likely to suggest these types of services for students with special needs.

Another norm in schools and elsewhere is to consider the symptom bearer to be the unit of intervention. For students with special needs, this norm should shift to viewing the whole family as the unit of intervention. This norm would likely shift if training in family systems concepts were to begin to make an impression on school professionals.

Shifts in norms are slow to occur and most likely follow training. It seems that a grass-roots or top-down authoritative pronouncement would be the only ways in which a shift in norms initially could be generated in the school system. Since a grass-roots approach is unlikely, someone in the school system would presumably have to assume responsibility for generating interest in family systems. School professionals would need to be given permission not only to know about the family systems concepts but also to use what they have learned without feeling they have crossed a professional boundary.

\section{School Procedures}

Many school procedures make it difficult for school professionals to implement or teach their knowledge about family systems. Social workers who are familiar with family systems concepts may have such large ease loads that they do not have the time to help other school professionals learn about family systems approaches. With budgetary problems and shrinking dollars, it is unlikely that school procedures will change in the near future.

The past emphasis on the placement of school counselors in each elementary school building was a hopeful sign that the use of family systems approaches could increase and develop. It augured well for the investment of energies and money in family systems concepts. Recent changes in state policy in Virginia, however, have shifted the responsibility for this decision to the local schools.

Adding to the problem, school counselors may be unfamiliar with family systems concepts or may not have the time to implement their knowledge and skills learned about family systems. Many elementary school counselors work with children rather than families. They often work quickly with a group of children for a short period and then move on to another group so that more may be served.

Secondary school counselors are almost always in charge of scheduling and have little, if any, time for counseling students, let alone families. Secondary schools are oriented toward noninterference with families. Students are viewed 
as old enough to be responsible for themselves and to accept natural consequences of behavior. Trying to elicit family support is often seen by professionals and families as enabling students to remain immature and dependent.

Finally, most educational teams do not function in a way that would allow collaboration with family systems. The teams often do not meet regularly and communicate mainly through written report; they may have only enough time for the barest of information sharing during team meetings. Once a student is determined to be eligible for special education, the collaboration of team members often decelerates. The teachers are often on their own until the IEP is revisited a year later.

\section{REALITY CONSTRAINTS}

A number of reality constraints also limit the use of family systems concepts and approaches in the school. The three reality constraints of time, money, and availability of trained personnel are seen most frequently.

\section{Time}

The constraint of insufficient time is a concern of all school professionals. However, once school staff have been trained and are competent in implementing family systems concepts, their knowledge will save them time. Over the long term, less time will be expended mired in an individual perspective when a family systems perspective will more easily resolve the problem.

\section{Money}

Finding money for staff development and for the release of personnel to attend training sessions is a real concern. With shrinking dollars, staff development funds may be among the first to be decreased. However, over the long term, the full implementation of family systems concepts may save dollars. Consider the example of students with emotional and behavioral disorders. If the whole family were seen as the unit of treatment, many of the problems would be resolved and the students would remain in classes for the seriously emotionally disturbed for less time. It is also likely that fewer due process hearings, which are very expensive, would be needed.

\section{Training}

The lack of trained personnel is another reality constraint. As mentioned earlier, changes in the institutions of higher education are slow to develop. With the emphasis on restructuring in the past several years, little energy is left for new endeavors and changing programs of study. Arends (1990) pointed to the slowness of universities to respond to criticism. He suggested that "teacher preparation of the future could be under the auspices of inspired and well-funded district-based human resource development units or state-based special academies for teachers" (p. 117-143).

The expenditure of initial funds for staff development in school systems would be invaluable. Again, a trainerof-trainers model that allows more people to be reached with fewer funds is useful. Furthermore, schools of social work and psychology at universities and colleges are excellent resources for those who might design modules as well as train trainers.

\section{ATTITUDES, RESISTANCE, AND CHANGE}

Attitudes are an intriguing phenomenon. They are defined as strong beliefs or feelings toward people and situations. We acquire attitudes, both favorable and unfavorable, throughout our lives. Attitudes involve a for or against quality that makes them obviously an attitude as opposed to an opinion. A poster often seen in schools bears the slogan, "Attitudes are contagious - are yours worth catching?" This is a great way to think about attitudes. It becomes obvious that individuals with positive attitudes toward change will bring about positive results.

M. Scott Peck (1978), the author of The Road Less Traveled and other wonderful books, stated, "It is only through a vast amount of experience and a lengthy and successful maturation that we gain the capacity to see the world and our place in it realistically, and thus are enabled to realistically assess our responsibility for ourselves and the world" (p. 37).

Negative attitudes and resistance to change can greatly limit the incorporation of family systems concepts into the school system. Both must be understood to make way for effective change. Further, a model for change is helpful in understanding, expecting, and validating concerns of employees about the change process.

\section{Negative Attitudes}

The most prevalent attitude that limits the use of family systems concepts in schools is: "It is someone else's responsibility to work with those families. I do not have enough time. What do they expect from us anyway? It is not in our job description. Our local education association or federation will support us on that."

Another negative attitude toward change stems from fear of failure and associated repercussions. Teachers and principals, in particular, might be concerned about employing strategies usually reserved for counselors, social workers, and psychologists. A natural concern relates to how the use of change strategies might result in a setback, as opposed to the growth and development, of the family. Without extensive training and well-understood boundaries regarding who 
employs these strategies, these fears would be well grounded. Obviously, this is a fear that needs to be addressed by anyone implementing change.

Negative contagion, a third attitude problem, may occur in some schools where teachers have bonded together to block anything new and different. They denounce new endeavors as "old wine in new bottles." As a group, they form a prodigious force that is hard to convert.

\section{Resistance}

It is important to recognize that resistance to change is normal human behavior. Orelove and Sobsey (1996) recommended that school professionals expect resistance to change, confront it, and focus on the common goals of the team that benefit children. People resist change for a variety of reasons. In an edited text on teamwork in education, Roy (1995) listed reasons for people's resistance to change:

- New goals are not accepted.

- People fear the unknown.

- People fear failure in the new situation.

- People like the current situation and arrangement.

- Reasons for change are not communicated well enough.

- People do not like or trust the individual or group initiating the change.

- New goals are unimportant to people.

- The changing environment is seen as an opportunity to oppose management.

- People fear loss of status, rights, and privileges.

- People resist change because it's change. (p. 86)

Focusing on the human side of change, Rosabeth Moss Kanter (1995) listed the following reasons people most commonly resist change in organizations: loss of control, excess uncertainty, Surprise? Surprise?, the "difference" effect, loss of face, concerns about future competence, ripple effects, more work, past resentments, and sometimes the threat is real. She suggested tactics for working with resistance and identified 14 ways to build commitment to change:

- Allow room for participation in the planning of the change.

- Leave choices within the overall decision to change.

- Provide a clear picture of the change, a "vision" with details about the new state.

- Share information about change plans to the fullest extent possible.

- Divide a big change into more manageable and familiar steps; let people take a small step first.

- Minimize surprises; give people advance warning about new requirements.

- Allow for digestion of change requests-a chance to become accustomed to the ideas of change before making a commitment.

- Repeatedly demonstrate your own commitment to the change.

- Make standards and requirements clear-tell exactly what is expected of people in the change.
- Offer positive reinforcement for competence; let people know they can do it.

- Look for and reward pioneers, innovators, and early successes to serve as models.

- Help people find or feel compensated for the extra time and energy change requires.

- Avoid creating obvious "losers" from the change. (But if there are some, be honest with them-early on.)

- Allow expressions of nostalgia and grief for the pastthen create excitement about the future. (p. 679)

These are lessons that everyone can take to heart when participating in a school renewal or other change processes.

According to Reece and Brandt (1987), some individuals resist change because they feel inadequate. Some feel their security is threatened; others may not trust those in charge of the change process. Some individuals who resist change have such a narrow focus that they simply do not see the larger picture.

\section{Feelings of Inadequacy}

When people learn new skills, they generally accept additional responsibility. That, in turn, may stretch their abilities and make them feel a lack of self-confidence. For example, most school professionals felt uncomfortable with computers until they became computer literate. The same will be true with family systems concepts. It is very important to support professionals who are learning these new skills. All professionals should feel that they can and will make mistakes as they learn; permission to learn from mistakes is important. Sharing stories with others and exchanging ideas for problem solving also can be very helpful. Those who are newly implementing family systems concepts and strategies will learn quickly that they are not the only ones who lack confidence and feel inadequate. Groups are great vehicles for mirroring and learning more about oneself.

\section{Issues of Security}

As Maslow (1970) made clear, personal security, both physical and psychological, is a very basic need. When the expectations for school professionals change and they are faced with making major changes in their work, some may worry that if they are unable to keep abreast of the changes they may be phased out or seen as less worthy. It is therefore important to make certain that school professionals know that the individuals in charge of the change process have the responsibility of preparing them adequately for the implementation of family systems strategies. Any lack of understanding or failure of implementation should be met with a careful check on the preparation of the employee and the necessary coaching provided to reach an appropriate mastery level. 


\section{Issues of Trust}

Lack of trust is another reason people resist change. Where the implementation of family systems concepts is concerned, mistrust is aimed at those responsible for directing and implementing change. There may be large differences among schools within one system, depending upon how much the principal is trusted. When school professionals are let in on upcoming changes only after all of the decisions and planning are complete, they are less likely to trust and therefore may resist even the most appealing change. It behooves the change makers to solicit input from representatives of all levels and types of school professionals. Furthermore, these representatives should be professionals who are trusted by their peers. Anyone perceived as a Yes Wo/man will not engender automatic trust.

\section{Narrow Focus}

Many school professionals will be unable to see the larger picture and will not understand that the learning of family systems concepts will pay off in the long run in terms of both time and money. Furthermore, they may not see the most important benefit, which is that the needs of at-risk and special-needs students will be met in a more satisfactory manner. To eliminate or minimize this form of resistance, it is imperative to explain the overall picture and reasons for the change, including family systems concepts and strategies.

\section{Change: Response Stages, Concerns About Change, and Stages of Growth}

The process of effecting lasting and meaningful change is complex and challenging. The literature on change is replete with advice about initiating change within educational institutions (D. F. Bradley \& King-Sears, 1997; Briggs, 1997; Caine \& Caine, 1997; Corbett, Firestone, \& Rossman, 1987; Evans, 1993; Giangreco. Dennis, Cloninger, Edelman, \& Schattman, 1993; Guskey, 1986; Haimes, 1995; G. E. Hall \& Hord, 1987; Sarason, 1982, 1996a, 1996b; Showers, Joyce, \& Bennett, 1987). This section discusses stages of response to change, concerns about change, and stages of growth.

\section{Stages of Response to Change}

M. Moore and P. Gergen (1989, cited in Haimes, 1995) identified four stages experienced by staff members in response to change: shock, defensive retreat, acknowledgment, and adaptation. Initially, people feel threatened by change, and their ability to relate to the change is impaired by their feelings. It is important to provide the necessary time for them to adjust to the changes and to discover what their roles in the change process will be. They need to be able to express their concerns, fears, and frustrations before planning is even broached.
Next, defensive retreat occurs, where people try to return to the "old way" of doing things. I conduct a training exercise where I have everyone stand up, bring their arms out to their sides in mid-air, then bring their hands together clasping them with fingers interlocked. Then I tell them to note which thumb is on top. I instruct them to pull their arms apart again and reclasp them with the nondominant thumb on top. We go through a series of these simulations (e.g., putting an arm in a jacket, jumping out to an imaginary rock), each time alternating the customary way and the new way. We then discuss which way feels better and which they plan to use the next time they put on a jacket, jump to a rock, or clasp their hands. Nobody wants to move out of their comfort zones, and it is critical to honor that human trait. During the time of defensive retreat, leaders can let staff members know what will not change, as well as what areas will likely be uncomfortable. Clear expectation about roles is important during this stage of reaction to change.

Acknowledgment involves school professionals' recognition that something good may result from the change for them and the students. The sense of loss is being replaced by excitement and anticipation as well as interest in their personal involvement. Planning commences, and people look to the future. Risk taking should be reinforced, as should be a focus on what people are learning.

Adaptation relates to the assumption of roles, routines, and methods that are new. During this implementation phase, those people who are not on board will become evident. They may be simply stuck in an earlier phase longer than the rest and not really resistant to change. Some of these individuals eventually will move through the earlier phase into the adaptation stage. Some, however, may not find it possible to make the adaptation.

\section{Concerns-Based Adoption Model}

This section presents information on the Concerns-Based Adoption Model (CBAM). It is highlighted because of its attention to the concerns of school professionals and, therefore, its ability to affect attitudes toward change. The model focuses on personal aspects of change. Change is seen as a process and not an event (G. E. Hall \& Hord, 1987). Further, it emphasizes the need to understand the point of view of participants who are involved in the change process. Idol et al. (1994) used CBAM in implementing Collaborative Consultation, as did Erb (1995) in relation to teamwork in middle school education. This model continues to be seen as a viable aid in the family systems field.

The CBAM model has three dimensions: stages of concern, levels of use, and innovation configurations. This discussion addresses only the stages of concern. Discussion of the other dimensions can be found in Hall and Hord (1987). 
G. E. Hall, R. C. Wallace, and W. Dossett (1973), and later G. E. Hall and S. M. Hord (1987), delineated seven levels of concern about change that relate to how school professionals feel about an innovation. They called the lowest stage of concern Awareness and assigned it a value of zero. In this stage, school professionals have little concern about or interest in the innovation. This is the level of concern people have toward something about which they know little or nothing.

The next stage of concern, Informational, reflects a general awareness of the innovation. The professional will have an interest in learning more about the innovation or change. At this stage, professionals are not concerned about how the change will affect them. They generally are concerned about aspects of the innovation such as its characteristics, requirements for use, and effects of the change. The developers of the model assigned a value of 1 to the informational stage of concern.

Personal concern, assigned a value of 2 , occurs when the professional is uncertain about the professional demands of the innovation as well as his or her personal adequacy in meeting those demands. The professional might analyze his or her role in relation to rewards in the organization and in relation to decision-making processes and find these to be of personal concern at this time. Potential conflicts with current commitments also could be of concern. Financial and status implications are other potential personal concerns.

At the next level of concern, Management, professionals focus their attention upon the processes and tasks involved in using the innovation as well as the best use of information and resources. Of prime concern are issues that relate to organizing, managing, and scheduling the innovation, as well as efficiency and time considerations. This level of concern was assigned a value of 3 .

A value of 4 was assigned to the stage referred to as Consequence. In this stage, professionals focus their concerns on the impact of the innovation on their particular students. Relevance to the lives of their students is of concern, as are outcomes and changes 'needed to increase the outcomes of the students.

The Collaboration stage, with a value of 5, has to do with concerns about coordinating with others. Professionals will want to know about ways to cooperate with peers in using the innovation.

In the final stage, Refocusing, with a value of 6 , professionals are concerned with how the innovation might benefit others. Some professionals might be concerned about alternative innovations. It is certain that professionals will have definite ideas and opinions about proposed or existing forms of the innovation.

With knowledge of this model, professionals can anticipate what will occur during a change process. A basic premise of the model is that anyone can be a change facilitator. Anyone can expedite the change process and facilitate, rather than manipulate, change. The facilitator would know about individual concerns and respond to them so that others would be more effective in applying innovations. Understanding the CBAM model can help the professional in any change effort he or she might initiate.

\section{Stages of Growth and the Process of Change}

Virginia Satir spoke and wrote about the stages of growth we go through in life as individuals, couples, families, and organizations (Dodson, 1991). She identified the stages as status quo, introduction of the foreign element and resistance, chaos, new integration and practice, and finally the new status quo. Satir's change model is highlighted here because of its family systems perspective.

Rosabeth Moss Kanter, mentioned earlier in this article, referred to those assuming responsibility for change in an organizational system as change-masters. I use this terminology in this section, even though it was not one of Satir's terms.

Dodson (1991) wrote, "Concepts behind Virginia's model for change were systems theory, life as a process, the inner healer in everyone and the need for education to aid change" (p. 122). Satir saw her model for growth and change as applicable to all domains. Her view of change stemmed from her seeing the world through what she called the systemic organic and seed model. The organic model is influenced by holistic concepts that hold that human beings have an inner drive to grow and develop. In awakening the healer(s) within, individuals and groups can engage in conscious choices to individuate and contribute to an expanding world. Essential to the growth process that Satir spoke of is self-esteem, and essential to the development of high self-esteem is an environment rich in nurturance and the freedom to explore and to know, as well as comment on, what is experienced. Satir applied her model for change "to education, prevention, individual, couple, family therapy and world healing" (Dodson, p. 122).

In the educational context, becoming conscious of change is critical for individuals, families, and schools. Otherwise, change is random and haphazard, and neither professionals, students, or their families will own the change process or outcome. A description of each of Satir's five stages follows. Within the descriptions, I have provided examples from my experience of being a university faculty liaison with urban schools moving toward site-based management.

Status quo. We are all familiar with the status quo. Things operate as usual, and we know what to expect, which may be that problems will pop up daily. The status quo may be 
very painful, yet is known and feels safe. Although we may realize that change is needed, we are fearful because we do not know what will happen if we move out of our comfort zones, even if they are unhealthy and unreasonable.

When an individual, family, or group such as a school consciously chooses to reach out toward something different, the motivation to do so generally stems from one of three stimuli. An individual, family, or group, such as a school or a team within a school, will want to change because the way things are operating is intolerable. Another version is that an individual, family, or group sees a possibility for something more enriching. Here, the vision of one person or group can provide the necessary motivation for change to begin. In the last version, the individual, family, or group is experiencing so much pain that it feels as if change must occur.

When I was a liaison with urban schools, the motivation for change came from the second stimulus, a vision. In this case, a grant provided funds to link schools with university liaisons and training so that site-based management could evolve more easily. The schools decided whether or not they bought into the vision.

It is not unusual for the problem that initiates a change process to relate to coping mechanisms that once served a useful purpose but no longer meet the needs of the individual or group. Whatever the motivation, in this first conscious stage of change people must become aware of what no longer functions to serve them. Because people fear change, they will resist (see preceding section on resistance) coming into awareness about their current function/dysfunction.

When people are in this phase of resisting yet obviously needing to grow, the change-master serves the growth process best by instilling visions for new possibilities. Imagery exercises are useful for this purpose. Imagery speaks to the deeper self, and that part of the self that has hope can speak to the part of the self that is fearful. In a group, the change-master can ask one person to take the hopeless and fearful side'with regard to a proposed change and another person to respond from the hopeful or visionary side. Fear must be validated and not squashed before moving forward. Once the fear is validated, it becomes possible to dream of new possibilities. Some Native American tribes have dream catchers (Malatchi, 1997) that serve this purpose. It is important to unleash the process of dreaming for change to move forward.

Questions for the change-master to pose to facilitate the process of dreaming were offered by Dodson (1991):

1. "If I visited you and the change that you want had happened, what would I see?"

2. "If you had a magic wand and could make one thing different in your life (in your family [team/school]), what would you most want to make different? If that were different, how would that help you?"* (p. 124)

Dodson indicated that it is important to be very aware of the body language of the person who is responding to these questions. It is possible to see fear and gauge your next response accordingly. Again, fear must be validated, or it will control the process of change. Empathy as well as patience are also important for change-masters. When this level of sensitivity is displayed, individuals within groups will begin to trust the leader and the relationship will deepen, a necessary ingredient for later stages in the process. The leader serves as a partner in exploring the new possibilities by encouraging the people involved to see, hear, feel, know, and share their experiences as well as their desires.

With the group having moved this far, the next step is to explore more deeply the nature of the status quo. What has been implied can be made explicit. What has been unconsciously done can be brought into awareness. Then a conscious choice can be made for growth and change.

Satir had a few particular examples that she used in this phase (Dodson, 1991). In demonstrating the status quo, Satir would speak about a mobile over a baby's crib and how all the figures in their place kept it in balance. Removing one would affect all the others, and the status quo would be disrupted. She likened this to what happens when change affects members within a family or teams within a school.

A second image Satir used was that of a teeter-totter with a heavy person on one side and a light person on the other. The heavier person, sitting close to the center for balance, is not having much fun. The lighter person, having to lean far back, is on the edge. Neither person is in a comfortable position, although they are keeping things balanced. She used this imagery to help others recognize the price that is paid for balance.

Satir's third image was that of an individual (and I would add group, team, or school) standing in concrete. The individual may be upright, but he or she cannot move. This very real imagery conjures up feelings of entrapment, of being frozen or stifled.

Generally, a change-master will offer an image and will then invite those involved to bring their own images to the table, making the exercise more meaningful. The images offered by the group members speak to the deeper self and, therefore, have more power to catalyze energy for change.

During this stage, as well as all the others, it is important that the leader accept the experiences shared and not judge, criticize, or put anyone down either verbally or nonverbally. Satir believed that all human beings have the capacity for change and that anything anyone has done can be rehabilitated. The more successful change-masters are those who are able to accept and forgive as well as nurture and support. 
Introduction of the foreign element and resistance. The next ştage in Satir's model of growth and change involves the introduction of a foreign element and resistance to that element. Foreign elements include new as well as inner desires to make changes. Resistance to change, described in a preceding section of this article, is an expected and normal part of the process of change. Satir (1988) referred to this stage as reshaping the status quo.

Change involves a form of loss or death of a part of the self or loss of the typical patterns for functioning in a group. In the same way that the body rejects a transplanted organ, we will resist and reject changes in our typical patterns. We are not comfortable wearing, and do not want to wear, a "tight, new pair of shoes." When we resist change, we are trying to maintain balance or homeostasis.

Change-masters need to be attuned to the natural tendency people have to direct their discomfort with change toward the agent of change. People may express anger toward or criticize the leader of change. The change-master may feel inadequate or think he or she is not doing things the right way. Alternatively, he or she may view the individual, family, or group/team as impossible. These are all signals that the group is in the stage of resistance. In this stage, it is important for the change-master to be in a place of nonattachment to the results of the change process.

When I served as a faculty liaison in urban schools, I experienced the discomfort of the professionals the planning and management team were attempting to "bring on board." The team members, a vital and energized group of trained professionals, were excited about the prospects of site-based management. At 3:00 on a Friday afternoon, they asked me to make a presentation at an in-service the following Monday morning to explain more about the process to their colleagues. Needless to say, it was a setup. Fortunately for me, I had been trained in Seymour Sarason's psychoeducational model during my doctoral program at the University of Kansas. I knew what to expect, even if I could not mitigate the losses I anticipated.

I was the brunt of 'some very strong anger. There were teachers sitting in the back of the room doing other things and not participating in the experiential exercises. This was obviously the norm in the school, as everyone acted as if "the Elephant in the Cafeteria wasn't there"! I stayed steady, did my best to be authentic, and discussed the situation with the principal during a break. She had never dealt with the nonparticipating teachers successfully and referred to them as her nemesis. It appeared that I was experiencing guilt by association.

The change-master during this stage must draw on his or her personal sense of satisfaction and appreciation. He or she must be self-supporting rather than dependent upon others for recognition. Aligning with the momentum of positive energetic change is critical, whether it is with an individual or group/team. Almost paradoxically, the leader must also be aware of and honor the fear others have about change. Change is a both/and proposition-both hopeful and anxiety provoking.

A graphic way of depicting the pull on individuals at this stage is to have one person stand up, have a second person, representing the force for hope, pull that person from the front, and have a third person, representing the force of fear and speaking in shoulds and oughts, pull the person from behind. The change-master would focus all three on how it feels to be in their respective positions and may have two of the people dialogue with each other. Satir also was known to have a fourth person play the observing ego or evolved self. This part would speak with the other parts and provide advice when a stalemate occurred as well as at other opportune times.

It is also beneficial for the change-master to help the individual or group/team focus on the courageous aspect of the self that has chosen to be involved in the change process. The person or group/team could be asked to get in touch with the courageous aspect of the self and journal or dialogue out loud with that part of the self, moving back and forth from the fear part to the courageous part.

Also, the change-master might find an opportunity to address the fear and hopelessness that runs deep in some people and groups. If a person were to say, "I don't know what makes you think anything will be any different," the change-master could respond with a more direct statement like, "It sounds as if you think I may fail you as others have and then you will be in a worse place because you would have made another commitment and be disappointed again." Satir said such interaction allows the leader to make contact with the person. It allows the change-master to go beyond the resistance and be in a deeper place with the person's fears and losses, rather than with the anger often stirred in resistance. It also allows for contact with the higher self of the person, that which the person is capable of becoming.

Chaos. Whereas the status quo is predictable and comfortable, Satir's third stage, chaos, is anything but that. It is not unusual for individuals, families, teams, and schools to ask for help with change when they are in crisis. Often, what they are really seeking is help in returning to the homeostasis that preceded the crisis. Yet, the crisis may be the very thing that will allow for a shift in a healthier direction that will move the individual or group past where things were before the crisis and into an improved pattern of being. Thus crisis, which the Chinese depict as two characters, brings both danger and opportunity.

Crises signal a need for people to listen more deeply, whether to the deeper self or to others. A responsibility of the change-master at this stage is to help people listen more 
deeply, thus helping them move toward new possibilities. As in the previous stage, imagery is helpful because it speaks to the deeper self. It is also important for the change-master to know and communicate to others that chaos is a positive and necessary step in the right direction. I recall Satir saying something like, "I am concerned when everything is going along well because when there is no chaos, there is no change."

Feeling vulnerable is part and parcel of this stage. Thus, another task of the change-master is to help people feel safe. If the change-master can protect people from being harmed by others, through reframing and other means, he or she will be more successful in charting these turbulent waters. If people open up to their vulnerabilities, they will more likely discover their inner truths.

When people feel vulnerable, they may get upset and sound off. When someone overreacts in this way, the leader needs to do some detective work to determine what set the person off. It may be that a situation recreated an earlier wound, and the infusion of energy was really related to past history. The person may not even realize he or she was overreacting. It may help to direct the person who is upset to look within, to be still in order to see what is underneath the expression of feelings in the outburst. Going deeper will certainly bring another foreign element into play, but that is part of the movement forward. Most people will need time to reflect on such circumstances before they will be able to use them to move forward in their growth process.

Because individuals and teams may perceive this stage as a backward movement, it is incumbent upon the changemaster to frame the chaos as necessary. It is helpful to have mentioned ahead of time, during Stages 1 and 2, that chaos is predictable and painful and necessary for growth. When people experience what was expected, it is usually easier to frame the experience in a more positive manner.

The change-master must remain rock solid during this stage. Serving as a model, the leader helps people move into and through fear-based views of the world. Being congruent is a necessity. While remaining neutral and nonjudgmental, the leader can point out the dysfunctional stances.

Satir (1983a) maintained that "the problem is not the problem." It is the way of coping with the concern that is the problem. This is true in all domains. To help people change unhealthy coping mechanisms, the change-master can encourage them to honor the five freedoms, remain congruent, and help them be in touch with their inner experiences as well as their feelings about these experiences. The feeling about the feeling is important. It is one thing to feel angry and another to feel guilty about feeling angry. Once these feelings are discovered, coping mechanisms used in the past can be changed.
Chaos theory is a current interpretation of disorder with a systems perspective. Professionals from many different fields of science theorize in order to make sense of the world. For a long time, scientists theorized about the world as predictable. In chaos theory, scientists look at nature as complex and dynamic, and they see it as whole. Chaos theory holds that underneath disorder and unpredictability is pattern. One must wade through the disorder to find the pattern. Similarly, where change is concerned, disorder is part and parcel of the movement forward, and those involved must learn to flow with the disarray or at least to tolerate it as a necessary step in the right direction.

During the chaos stage, I always try to remember that the worst that can happen is that things will return to the way they were before. This helps me to not become overwhelmed by the chaos or its impact upon others. In one of the urban schools for which I served as faculty liaison, I was careful to predict the stage of chaos ahead of time. The members of the planning and management team, aware of the necessity for chaos, would joke about this "sign of progress" and stay centered, while the rest of the school professionals lumbered about, trying to avoid ownership of the site-based concept.

In the same school, I advocated that I or someone else facilitate a workshop during which people who were not on board would be given the opportunity to place their fears and frustrations on the table. I got nowhere with this idea and had to let it go. The school professionals were not ready for that much authenticity and had not reached a point of trusting me, or anyone else on the team, enough to let all of their negative feelings about site-based management surface. There was even resistance to that level of intimacy within the planning and management team. Members of the team feared that opening themselves up would result in the creation of bigger barriers rather than the breaking down of barriers. From that response, I unfortunately went into a place of less hope and pulled back from my involvement. I do not believe it is possible for individuals to effect authentic, system-wide change if they are holding back out of a realistic fear of reprisal.

New integration and practice. This stage is a time of growing comfort with the new. The old, automatic responses and ways of interacting and doing things have gone, and new possibilities have replaced them. Hope is rebirthed, and it feels a little like springtime internally. Once the individual, family, team, or group has moved out of chaos, it is time to integrate and practice the new patterns. Practice is necessary to validate, confirm, and reconnect to oneself and others. It is a time of being conscious of one's actions and not doing things on automatic pilot. 
In this phase the change-master needs to remove him- or herself from a directive role and turn power over to the individuals, group, or team. In my role as faculty liaison, I had the experience in one school of observing the principal rotate out of the responsibility for facilitating the planning and management team meeting. The principal consciously chose to continue being just another voice on the team. The team eventually moved on without her presence as facilitator. While she would have been ill-advised to be absent frequently during the first three stages, I always considered it a gift that she was not always present during later stages because it showed her respect for the team process in decision making, and it helped the team members absorb the new possibility - that of leadership being everyone's responsibility.

As part of the shift in power, the change-master needs to restrict him- or herself to asking questions rather than answering them. In the school just mentioned, I frequently had to bite my tongue when I was asked "how things should work" by the team members. Whereas in the earlier stages I needed to play a more direct role, the point of moving to site-based management was to empower people and to share leadership so that the ownership would flow over and result in better things happening for the students. My stance, as well as the principal's, allowed the team to practice their new ways of being together and their newly established patterns of shared leadership and it gave them the opportunity to learn from their mistakes as well as their successes.

The change-master's role at this stage is to cheer and validate the new growth by pointing it out and focusing on it in concrete ways. At the opening meeting of the planning and management team in the second year of my involvement with one school, I chose to use my part of the meeting to share a list of all the things that I thought the team had learned and the processes that were working well for them as a leadership team. Equally important is to support people in authentic ways when they are straying off target or reverting to old patterns. Without support, the person or group may, out of fear, revert to the old ways. The role of the change-master is exquisite when done well. It is a matter of being totally present, aware, and supportive.

In one school, when we were in this phase of practice, I did take a directive role in recommending that the team look at the process they were now using in comparison to what they had earlier identified as their preferred pattern. Team membership had become so large that participation had dropped off. Furthermore, the team members had become overworked from what seemed to me to be too frequent meetings and had lost some of their enthusiasm. When presented with my observations, they agreed that I was on target. We moved to reduce membership and meet less frequently. The results were positive for all involved.

The new status quo. The adage "Good better best, never let it rest, until the good is better and the better best" fits in this final stage of Satir's growth model. The practice has paid off, and people are no longer in danger of regressing to their old patterns. Usually people feel more creative, energetic, vital, and connected. And, as they have achieved another status quo, they eventually will move into another period of growth and change. I have worked with schools that moved quite a distance in a short time and then needed time to settle and function normally for a while. It takes considerable energy to move through planned change, and it is not necessary to be actively involved in change processes at all times. In fact, there are times when that is ill-advised.

What is important is to look underneath the new status quo situation and see what is driving it. If fear lurks, it is a signal that people are not being authentic or not listening deeply to themselves and others. It signals that there is an imbalance, and in such cases it is important to move into a new process of change. Renewal is the catchword of the day, and its importance can't be overemphasized in the context of the ever-changing universe to which we all must respond. It is infinitely possible to be growing while maintaining a form of status quo. Staying in touch with one's experienceswhat one sees, hears, thinks, feels, wants-and commenting on them is critical to healthy living.

I have found Virginia Satir's model for growth to be one that makes intuitive sense. I have also found it to be an excellent resource when professionals want me to consult with them on organizational transformation. I teach the model to prospective leaders at the university and always find that it opens doors rather than closes them. If leadership is everyone's responsibility, which I believe it is, then the model provides vital information for everyone.

I leave you with one of my favorite readings. Attributed to Lao Tzu in the sixth century B.C., it speaks to the heart of my vision of leadership. For anyone wishing to implement systems models, perspectives, and approaches in their work lives, this philosophy of leadership will serve you well. It is a philosophy I adopted long ago. Like a compass, it helps me find my center on a daily basis.

Of the best leaders, the people only know that they exist. The next best they love and praise,

And the next they fear and revile.

When they do not command the people's faith

Others will lose faith in them and resort to recriminations

But of the best, when their work is done

The people will all remark, "we have done it ourselves." 


\section{SUMMARY}

I believe in possibilities. Experience has taught me that challenges can be met and that barriers can be broken. Books and articles abound on change. Change is a way of life, and problems associated with change are expected as well as predictable. The effort to use family systems concepts and approaches with at-risk and special-needs students will have a better chance for survival if professionals are more aware of the aspects of change and understand the implications of these aspects in school settings.

\section{REFERENCES}

Arends, R. I. (1990). Connecting the university to the school. In B. Joyce (Ed.), Changing school culture through staff development (pp. 117 143). Alexandria. VA: Association for Supervision and Curriculum Development.

Armstrong. D. (1995). Power and partnership in education: Parents, children and special educational needs. New York: Routledge.

Azpeitia, L. M., \& Zahnd, W. F. (1991). Increasing couple intimacy using Virginia Satir's temperature reading. In B. J. Brothers (Ed.), Virginia Satir: Foundational ideas (pp. 83-101). New York: Haworth Press.

Baldwin, M. (1993). Ingredients of an interaction. In T. S. Nelson \& T. S. Trepper (Eds.), lol Interventions in family therapy (pp. 17-21). New York: Haworth Press.

Björck-Äkesson, E., \& Granlund, M. (1995). Family involvement in assessment and intervention: Perceptions of Professionals and parents in Sweden. Exceptional Children, 61, 520- 535.

Bradley, D. F., \& King-Sears. M. E. (1997). The change process: Change for people and schools. In D. F. Bradley, M. E. King-Sears, \& D. M. Tessier-Switlick (Eds.), Teaching students in inclusive settings: From theory to practice (pp. 56-82). Boston: Allyn \& Bacon.

Briggs, M. H. (1997). Building early intervention teams. Gaithersburg, MD: Aspen.

Caine, R. N., \& Caine, G. (1997). Education on the edge of possibility: Alexandria, VA: Association for Supervision and Curriculum Development.

Carney, I., \& Gamel-McCormick, M. (1996). Working with families. In F. P. Orelove \& D. Sobsey, Educating children with multiple disabilities: A transdisciplinary approach (3rd ed.. pp. 451-476). Baltimore. MD: Paul H. Brookes.

Chapman. W. (1991). The Illinois experience: State grants to improve schools through parent involvement. Phi Delta Kappan. 72, 355-358.

Corbett, H. D., Firestone, W. A., \& Rossman, G. B. (1987). Resistance to planned change and the sacred in school cultures. Educational Administration Quarterly, 33(4). 36-59.

D'Angelo, D. A., \& Adler, C. R.' (1991), Chapter 1: A catalyst for improving parent involvement. Phi Delta Kappan. 72, 350-354.

Dodson, L. S. (1991). Virginia Satir's process of change. In B. J. Brothers (Ed.), Virginia Satir: Foundational ideas (pp. 119-142). New York: Haworth Press.

Erb, T. O. (1995). Teamwork in middle school education. In H. G. Garner (Ed.), Teamwork models and experience in education (pp. 175-198). Boston: Allyn \& Bacon.

Evans, R. (1993). The human face of reform. Educational Leadership, $51(1), 19-23$.

Falik, L. H. (1995). Family patterns of reaction to a child with a learning disability: A mediational perspective. Journal of Learning Disabilities. $28,335-341$.

Foster, M., Berger, M., \& McLean, M. (1981). Rethinking a good idea: A reassessment of parent involvement. Topics in Early Childhood Special Education, 1, 56-65.

Giangreco, M. F., Dennis, R., Cloninger, C., Edelman, S.. \& Schattman, R. (1993). "I've counted Jon": Transformational experiences of teachers educating students with disabilities. Exceptional Children, 59 $359-372$.

Green, S. K., \& Shinn, M. R. (1995). Parent attitudes about special education and reintegration: What is the role of student outcomes? Excep tional Children, 61, 269-281.

Guskey, T. (1986). Staff development and the process of teacher change. Educational Researcher, 15(5), 5-12.

Haimes. R. (1995). Planning for change. In H. G. Garner (Ed.), Teamwork models and experience in education (pp. 73-83). Boston: Allyn \& Bacon.

Hall, G. E., \& Hord, S. M. (1987). Change in schools: Facilitating the process. Albany: State University of New York Press.

Hall, G. E., Wallace, R. C., Jr., \& Dossett, W. (1973). A developmental conceptualization of the adoption process within edacational institutions. Austin: The University of Texas at Austin, Research and Development Center for Teacher Education. (ERIC Document Reproduction Service No. ED 095 126).

Harvard Family Research Project. (1995). Raising our future: Families schools, and communities joining together. Cambridge, MA: Author.

Idol, L., Nevin, A., \& Paolucci-Whitcomb, P. (1994). Collaborative consultation (2nd ed.). Austin, TX: PRO-ED.

Jenson, W. R., Sheridan, S. M., Olympia, D., \& Andrews, D. (1994). Home work and students with learning disabilities and behavior disorders: A practical, parent-based approach. Journal of Learning Disabilities, 27. $538-548$.

Johnson, D. (1997). Reaching out: Interpersonal effectiveness and self actualization (6th ed.). Boston: Allyn \& Bacon.

Kanter, R. M. (1995). Managing the human side of change. In D. A. Kolb, J. S. Osland. \& I. M. Rubin (Eds.). The organizational behavior reader (6th ed., pp. 676-682). Englewood Cliffs, NJ: Prentice-Hall.

Kay, P. J., Fitzgerald, M., Paradee, C., \& Mellencamp, A. (1994). Making homework work at home: The parent's perspective. Journal of Learning Disabilities, 27, 550-561.

Leithwood, K. (1997). Presentation made at Virginia Commonwealth University School of Education annual Scholar in Residence seminar.

Losen, S., \& Losen, J. (1985). The special education team. Boston: Allyn $\&$ Bacon.

Losen, S. M., \& Losen, J. G. (1994). Teamwork and the involvement of parents in special education programming. In H. G. Garner \& F. P Orelove (Eds.), Teamwork in human servtces: Models and applications across the life span (pp. 117-141). Boston: ButterworthHeinemann.

Malatchi, A. (1997). Family partnerships, belonging, and diversity. In L. A. Power-deFur \& F. P. Orelove (Eds.), Inclasive education: Practical implementation of the least restrictive environment (pp. 91-115). Gaithersburg, MD: Aspen.

Margolis, H., \& Brannigan, G. G. (1986). Relating to angry parents. Academic Therapy, 21, 343-346.

Maslow, A. (1970). Motivation and personality. New York: Harper \& Row.

McLoughlin, J. A. (1981). Training together to work together. Teacher Education and Special Edueation, 4(4), 45-54.

McMillan, D. L.. \& Turnbull, A. P. (1983). Parent involvement with specia education. Edacation and Training of the Mentally Retarded, 18, 5-9.

Miller, R. (1996). The developmentally appropriate inclusive classroom in early education. Albany, NY: Delmar.

Moore, M., \& Gergen, P. (1989). Managing risk taking during organizational change. King of Prussia, PA: Organizational Design and Development.

Morsink, C. V., Thomas, C. C., \& Correa, V. I. (1991). Interactive teaming: Consultation and collaboration in special programs. New York: Macmillan.

Nichols, M. P., \& Schwartz, R. C. (1995). Family therapy: Concepts and methods (3rd ed.). Boston: Allyn \& Bacon.

Orelove, F. P., \& Sobsey, D. (Eds.). (1996). Educating children with multiple disabilities: A transdisciplinary approach (3rd ed.). Baltimore, MD: Paul H. Brookes.

Peck, M. S. (1978). The road less traveled. New York: Simon \& Schuster.

Peeks, B. (1997). Revolutions in counseling and education: A systems perspective in the schools. In W. M. Walsh \& G. R. Williams (Eds.), 
Schools and family therapy: Using systems theory and family therapy in the resolution of school problems (pp. 5-12). Springfield, IL: Charles C. Thomas.

Pfeiffer, S. (1980). The school-based interprofessional team: Recurring problems and some possible solutions. Journal of School Psychology, I8, 388-394.

Power-deFur. L. A., \& Orelove, F. P. (Eds.). (1997). Inclusive education: Practical implementation of the least restrictive environment. Gaithersburg, MD: Aspen.

Reece, B. L., \& Brandt. R. (1987). Effective human relations in organizations (3rd ed.). Boston: Houghton Mifflin.

Roy, S. A. (1995). The process of reorganization. In H. G. Garner (Ed.), Teamwork models and experience in education (pp. 85-101). Boston: Allyn \& Bacon.

Sarason, S. (1982). The culture of the school and the problem of change (2nd ed.). Boston: Allyn \& Bacon.

Satir, V. (1983a). AVANTA Process Community III. The Third Intemational Summer Institute. Crested Butte, CO: AVANTA Process Community.

Satir, V. (1983b). Conjoint family therapy (3rd ed.). Palo Alto, CA: Science and Behavior Books.

Satir, V. (1988). The new peoplemaking. Mountain View, CA: Science and Behavior Books.

Satir, V. \& Baldwin, M. (1983). Satir, step by step. Palo Alto, CA: Science and Behavior Books.
Schwab, J. (1990). A resource handbook for Satir concepts. Palo Alto, CA: Science and Behavior Books.

Showers, B., Joyce, B., \& Bennett, B. (1987). Synthesis of research on self-development: A framework for future study and a state-of-the-art analysis. Educational Leadership, 45(3), 77-87.

Solomon. Z. P. (1991). California's policy on parent involvement: State leadership for local initiatives. Phi Delta Kappan, 72, 359-362.

Suelzle, M., \& Keenan, V. (1981). Changes in family support networks over the life cycle of mentally retarded persons. American Joumal of Mental Deficiency, 86, 267-274.

Sussell, A., Carr, S., \& Hartman, A. (1996). Families R Us: Building a parent/school partnership. Teaching Exceptional Children, 28(4), 53-57.

Turnbull, A. P. \& Turnbull, H. R. (1996). Families, professionals, and exceptionality: A special partnership (3rd ed.). Upper Saddle River, NJ: Prentice-Hall.

Walsh. W. M.. \& Williams, G. R. (1997). Schools and family therapy: Using systems theory and family therapy in the resolution of school problems. Springfield, IL: Charles C. Thomas.

Weber, J. L., \& Stoneman, Z. (1986). Parental nonparticipation in program planning for mentally retarded children. An empirical investigation. Applied Research in Mental Retardation, 7, 359-369.

Winton. P. J., \& Turnbull. A. P. (1981). Parent involvement as viewed by parents of preschool handicapped children. Topics in Early Childhood Special Education, 1, 11-19. 